ISSN: 1110-5623 (Print) - 2090-0570 (Online)

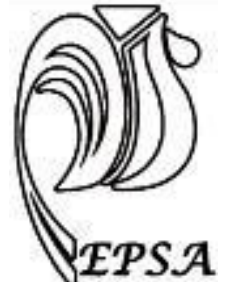

\title{
EFFECT OF DIETARY ZINC AND MANGANESE CHELATED WITH TRYPTOPHAN AND PROTEIN ON GROWTH PERFORMANCE AND CARCASS TRAITS OF QUAIL
} Ghada Mostafa El ashry

Regi. Cent. for Food and Feed, Agric. Res. Cent., Dokki, Giza, Corresponding author: Ghada Mostafa El ashry email: ghadaashry@ yahoo.com

Received: 06/06/2019 Accepted: $30 / 06 / 2019$

\begin{abstract}
The objective of this study was to determine the optimal dietary chelate of zinc and manganese on the growth performance, blood profile and carcass characteristic. A total number of 1050 unsexed quail chicks aged 7 days and averaged $23.7 \mathrm{~g}$ body weight were divided randomly into five groups (210 birds each), each group was subdivided into three replicates, each with 70 birds. Birds were kept under the same administrative, healthy and environmental conditions The five treatment groups were fed as follows: The 1 st group of birds was fed basal diet and served as control (T1), birds of the 2nd and 3rd groups were fed the same basal diet supplemented with $100 \mathrm{mg}$ zinc tryptophan chelate (T2) and $100 \mathrm{mg}$ zinc proteinate chelate (T3). While birds from the 4th and 5th groups were fed the same diets of control diet supplemented with $100 \mathrm{mg}$ manganese tryptophan chelate (T4) and100 mg manganese proteinate chelate (T5). Feed and water were provided ad libitum throughout the experimental period. The trial lasted 5 weeks. The results indicated that body weight gain and feed conversion coefficient were influenced by supplemental levels of zinc and manganese proteinate chelates, the hemoglobin concentration, packed cell volume and white blood cell were significantly higher in groups T3 and T5. Total cholesterol level, LDL-cholestrol and glucose decreased in T3and T5 treatment ( $\mathrm{Zn}$ and Mn proteinate chelate). However, HDL-cholestrol level, Albumin, AST, ALT, ALP and calcium were significantly increase with chelated minerals treatments. The effect of treatment on the carcass traits and relative weight of the lymphoid organs were significantly increased. It is concluded that supplementing diets of Japanese quail with $\mathrm{Mn}$ and $\mathrm{Zn}$ chelate especially with protein had great influence on performance, blood profile and carcass characteristics as well as improved the immune response
\end{abstract}

Key words: zinc chelate-Mn chelate- blood profile-carcass traits- immune response 


\section{INTRODUCTION}

The Japanese quail (Coturnix coturnix japonica) is gaining popularity as alternate meat bird with better growth and egg production. Japanese quail besides being a premium meat producing bird, has also been recognized as a pilot research animal (Wilson ,1961) as it offers easy handling, low maintenance cost, rapid generation turn over and good reproductive performances. To meet the mineral requirement, zinc $(\mathrm{Zn})$, copper $(\mathrm{Cu})$ and manganese $(\mathrm{Mn})$ are supplemented in poultry diets as an inorganic salts. But inorganic minerals tend to dissociate in the low $\mathrm{pH}$ environment of upper gastrointestinal tract, (Underwood and Shuttle 1999). Chelated minerals can be utilized at a much lower concentration in the diet than the inorganic sources, without a negative impact on production performance. Higher bioavailability of proteinates and amino acid chelates (Wedekind and Baker 1990, Wedekind, 1992, Cao, 2000) has resulted in increased use of these forms of trace minerals in feeding of livestock and poultry. Abdallah, (2009) observed that chicks fed diets containing $100 \%$ organic minerals $(\mathrm{Zn}$, $\mathrm{Cu}, \mathrm{Mn}$ and $\mathrm{Fe}$ ) had significantly higher body weight and better feed conversion compared with those fed inorganic minerals. Research on chelated mineral on the production performance of quail under practical feeding system is very few.

So, this investigation was undertaken with the objectives of evaluating the effect of chelated trace minerals ( zinc or manganese tryptophan and protein chelates) on growth, feed conversion, carcass traits, blood biochemical of quails. Since most of the research work on chelated mineral feeding has been reported in broiler birds and not much reference is available for quail, so the discussion of this research paper is mainly based on broiler birds.
MATERIALS AND METHODS

The present study was carried out at Poultry Research Centre of the Poultry Production Department, Faculty of Agriculture (El-Shatby), Alexandria University, during the period from March to April, 2017.

\section{1.chelated minerals source and preparation}

Chelated minerals under study (zinc and manganese chelated with tryptophan and proteinate ) were synthesized by mixing solution of 0.8 mole of zinc, 0.8 mole of manganese sulphate with 0.8 mole of tryptophan. Zinc and manganese proteinate were prepared by mixing of zinc sulphate, manganese sulphate and protein in 1:2 ratio. The reaction was refluxed for two hours and then left overnight where the complexes were precipitated, and then filtered washed with distilled water and dried in vacuum desiccators over $\mathrm{P}_{4} \mathrm{O}_{10}$. The melting points of the complexes are over $300^{\circ} \mathrm{C}$.zinc and manganese tryptophan, and proteinate chelates were digested and decomposed with aqua regia then zinc and manganese concentration were determined by by an atomic absorption Buchi (1974)

\section{2. birds and experimental design}

A total number of 1050 unsexed quail chicks, aged 7days and averaged $23.7 \mathrm{~g}$ were used. They divided randomly into five treated groups (210 birds each). Each group was subdivided into 3 replicates, each with 70 birds. Birds were kept under the same administrative, hygiene and environmental conditions.

The ingredients and calculated analysis of the experimental basal diet are illustrated in Table 1. Diet was formulated to cover the nutrient requirements of quail chickens as exhorted by the NRC, (1994). The basal diet consisted of $24.6 \%$ crude protein and $2902 \mathrm{kcal} / \mathrm{kg} \mathrm{ME}$ and the calcium level was $0.96 \%$ from 1 to 6 weeks of age. The five treatment groups were fed as follows: 


\section{zinc chelate-Mn chelate- blood profile-carcass traits- immune response}

The 1st group of birds was fed basal diet and served as control (T1). Birds of the 2nd and 3rd groups were fed the same basal diet supplemented with $100 \mathrm{mg}$ zinc tryptophan chelate (T2) and $100 \mathrm{mg}$ zinc proteinate chelate (T3). birds of the 4th and 5th groups were fed the same diet supplemented with $100 \mathrm{mg}$ manganese tryptophan chelate (T4) and100 $\mathrm{mg}$ manganese proteinate chelate (T5). Feed and water were provided ad libitum throughout the experimental period. The trial lasted 5 weeks.

\section{3. housing and husbandry}

Chicks were housed in breeding pens with fresh wood shavings; gas heater was used to provide the chicks with heat needed for brooding, in a well-ventilated open system and were kept under the same managerial, hygienic and environmental conditions. Ambient temperature was maintained at 33-35C during the 1st week and weekly decreased by $3{ }^{\circ} \mathrm{C}$ for the next three weeks. During the 5th and 6th weeks, temperature was maintained at $22-24{ }^{\circ} \mathrm{C}$. The mean relative humidity during the broiler period was $66.7 \%$. A light schedule similar to commercial condition was used; from one day old until 7th day it was $23 \mathrm{~h}$ light, followed by $20 \mathrm{~h}$ of light from 8th day and through the experimental period until last period of experiment (8-42 days of age).

\subsection{Data Collected}

\subsubsection{Data Collected For Quail's Performance:}

Individual live body weight, body weight gain, feed consumption and feed conversion ratio were weekly recorded during the experimental period, from two to six weeks of age.

\subsection{2. blood collection and hemato- biochemical analyses}

At the end of the experimental period, nine fasted birds from each treatment were randomly taken. Blood samples, about 2 $\mathrm{ml}$, were collected before slaughter from the wing vein under vacuum in clean tubes without anticoagulant, coagulated blood samples were centrifuged at $4000 \mathrm{rpm}$ for 15 minutes and the clear serum was separated and stored in a deep freezer at $20{ }^{\circ} \mathrm{C}$ until biochemical analysis. A part of each sample was used to assess the hematological parameters including red blood cells count (RBCs), hemoglobin $(\mathrm{Hb})$ concentration was measured according to Provan (2004), packed corpuscular volume (PCV), white blood cells (WBCs) and its differential count according to Feldman (2000). Serum glucose concentrations were measured by the (Trinder, 1969) using commercial kits. Blood serum was analyzed for concentrations of total protein, albumin, total lipids cholesterol, triglycerides, low density lipoprotein (LDL) and high density lipoprotein (HDL) using colorimetric method by commercial kits obtained from Reactivos GPL, Barcelona, Spain. Serum globulin was estimated by subtracting albumin values from the corresponding values of total protein. The transaminase enzymes activities of Aspartate amino transferase (AST) and plasma Alanine amino transferase (ALT) were determined by calorimetric method of Reitman and Frankel (1957).Alkaline phosphatase (ALP) concentration was determined according to the colorimetric method of Bauer (1982).Creatinine was assayed calorimetrically according to the method of Caraway (1963). Uric acid was determined colorimetrically according to Majkic-Singh et al. (1981).Serum calcium and inorganic phosphorus concentrations were determined according to Tietz (1986). Plasma concentration of total triiodothyronine (T3) was assayed by 
Ghada Mostafa El ashry

radioimmunoassay technique using kit from Diagonostic Products Corporation, Los Angeles, USA. Activity of malondialdehyde (MDA) and total antioxidant capacity (TAC)in blood serum were also analyzed (Reactivos GPL, Barcelona, Spain).Serum Glutathione peroxidase were determined by calorimetric method of Levander et al. (1983) and serum superoxide dismutase (SOD) was determined by Biodiagnostic kit (Biodiagnositc Company, Dokki, Giza, Egypt), according to the method of Nishikimi et al. (1972).

\section{5. slaughter procedure}

At the end of the experimental period, nine fasted birds from each treatment were randomly taken for slaughter, fasted for 12 hours, individually weight and slaughtered to complete bleeding then carcass were manually eviscerated and weighed to the nearest one gram. Dressing percentage included relative weights of carcass and giblets (liver, kidney and heart)were also measured. Spleen, pancreas, liver, heart, gizzard, intestine and cecum were removed and weighed separately to the nearest $(0.1 \mathrm{~g})$. The length of intestine and cecum were measured to the nearest centimeter $(\mathrm{cm}$.

\section{6. statistical analysis}

Data for all variables were subjected to analyses of variance (ANOVA) in order to assess the effect of $i$ chelated trace minerals (zinc and manganese) of using the general linear models (GLM) procedure in SPSS ${ }^{\circledR}$ statistical software (SPSS, 2016). Percentage data of the studied traits were transformed to arcsine before analysis, and significant differences among means were evaluated using Duncan multiple range test (Duncan, 1955). The statistical treatment used was as follow:
Yij $=\mu+\mathrm{Ti}+\mathrm{eij}$

Where: $\quad Y i j=$ The observation of the statistical measured.

$\mu=$ The overall mean.

$\mathrm{Ti}=$ The effect of treatment.

eij $=$ The experimental random error

\section{RESULTS AND DISCUSSION}

\section{Live body weight}

Table 2 shows the effect of adding different chelates of organic zinc and manganese to broiler feed. Body weight showed significant improvement $(p \leq 0.05)$ in treatment $\mathrm{T} 3$ and $\mathrm{T} 5$ ( $\mathrm{Zn}$ and $\mathrm{Mn}$ proteinate chelate) in comparison with control

\section{Body weight gain}

Table 3 shows significant differences in weight gain between control $\mathrm{T} 1$ and $\mathrm{T} 3$, T5 treatments at the age of 42 days. They registered $198.02 \mathrm{gm}$ and $199.10 \mathrm{gm}$, respectively.

\section{Feed Consumption}

Table 4 shows that there was significant increase of $(p \leq 0.05)$ in T3 and T5 where it registered $572.6 \mathrm{gm}$ and $581.25 \mathrm{gm}$ compared to $\mathrm{T} 1$ at 42 days

\section{Feed conversion efficiency}

Table 5 shows that feed conversion effeciency at age of 42 was significantly increased $(\mathrm{p} \leq 0.05)$ in $\mathrm{T} 2, \mathrm{~T} 3, \mathrm{~T} 4$ and $\mathrm{T} 5$ at age of 35 days. As they registered 2.90, $2.91,2.89$, and 2.93 respectively in comparison of T1 3.03.

Quail fed diets containing inorganic minerals significantly recorded the lowest live body weight. This is in agreement with the findings of Abdallah 2009. So, $\mathrm{Zn}, \mathrm{Mn}$ proteinate chelate showed significant improvement in body live weight, BWG and FCR. These results are in agreement with Gheisari. (2010) who reported that BWG and FCR were improved by supplementing broilers with $50 \%$ mixture from $(\mathrm{Zn}, \mathrm{Mn}, \mathrm{Cu})$ as an 
zinc chelate-Mn chelate- blood profile-carcass traits- immune response

organic minerals compared with adding $100 \%$ of these minerals as inorganic. These results were in agreement with Abdallah, 2009 who reported that chicks fed diet supplemented with $50 \%$ or $100 \%$ of $\mathrm{Zn}, \mathrm{Mn}$ and $\mathrm{Cu}$ as organic forms recorded better relative economical efficiency than those fed diet supplemented with $100 \%$ of inorganic forms for these minerals. On the other hand These results disagree with Mohanna and Nys 1998 who reported that weight gain, feed intake and feed conversion in broiler were not influenced by $\mathrm{Zn}$ sulphate or $\mathrm{Zn}$ methionine. The earlier workers reported no significant effect of $\mathrm{Mn}$ source on average daily weight gain. Henry, (1989). Baker and Halpin (1987) reported that Mn proteinate Vs sulphate had little effect on chick weight gain. The use of organic sources of minerals can improve intestinal absorption of trace elements as they reduce interference from agents that form insoluble complexes with the ionic traces elements Van der klis and Kemme 2002

\section{hematological characteristics of japanese quail}

The effect of supplementing Japanese quail with $\mathrm{Zn}$ and manganese chelate on $\mathrm{Hb}$ hemoglobin, packed cell volume PCV, red blood cells (RBC), white blood cell, Leucocyte, H/L ratio and monocyte were shown in tables (6and7). Hemoglobin level was significantly higher in groups T3 and T5 (Zn proteinate and Mn proteinate chelates) in comparison to control and other chelated groups. The increasing in hemoglobin among protein chelate supplementation could be attributed to its essentiality in erythropoietin. Zinc also plays a catalystic role in the activity of alfa-aminolevunilic acid dehydrogenase which is responsible for heme synthesis
Aksu ,(2010). The increase in hemoglobin and PCV could be attributed to antioxidants characteristics of chelated protein and their ability to improve the synthesis, stability and activity of enzymes in the body (Tayeb and Qader,2012).

In this respect, Fawzy (2016) reported that hemoglobin concentration increased while heterophill to lymphocyte ratio $(\mathrm{H} / \mathrm{L})$ decreased with chelated minerals. The H/L ratio has been accepted as a reliable index of determining stress in poultry (Gross, and Siegel. 1983). The better hematological parameters as observed in organic trace minerals may due to the fact that antagonism between metals can be avoided by using chelated form of these minerals Abdallah,(2009). Also, our results are in agreement with those reported by Ozturk-urek, (2001) who found that $\mathrm{Zn}, \mathrm{Mn}, \mathrm{Fe}, \mathrm{Cu}$, and Se trace elements are involved in the metabolic activities via mettalloenzyme which are essential for the antioxidant protection of chicken cells. Moreover, the organic trace minerals had some beneficial impact on immune system as well as in reduction of stress in the bird Wei, (2001).Aksu et al. 2010 observed that $\mathrm{Cu}, \mathrm{Zn}$ and $\mathrm{Mn}$ are important trace element for the development of the red blood cells. Also, when they used lower concentration of organically complexed minerals $\mathrm{Cu}, \mathrm{Zn}, \mathrm{Mn}$ in broiler diets instead of inorganic forms of these minerals didn't created a negative impact on hematological parameters. In the present study, the $\mathrm{H} / \mathrm{L}$ ratio in the control group was higher than with zinc and manganese protein chelate, which may be attributed to the possible reduction of glucocorticoid secretion or higher IL-2 production Ghazi,(2012). Therefore, the supplementation of OTM (organic trace 
Ghada Mostafa El ashry

minerals) to broiler chicken's diet can have beneficial role in reducing oxidation stress, thereby improving the overall health status of chickens.

As shown from Table (8), the addition of zinc and manganese chelate resulted in significant $(p \leq 0.05)$ increase in blood plasma protein and calcium in comparison with control group. These significant increase $(p \leq 0.05)$ may be attributed to the role of zinc in sex and steroid hormones synthesis and its action on the metabolism of sex steroids together with prostaglandins (Brawns and pentland (2007). The increase in plasma protein as compared to control group may be attributed to the hormonal regulation of protein metabolism. For example growth hormone increase the synthesis of cellular protein glucocosteroids and increased break down of most tissue proteins metabolism Wilson, (1961).

In our study, a significant decrease in the level of total cholesterol Table (9) in the plasma was found in zinc and manganese proteinate chelate. Our results confirmed previous findings which proved the positive impact of zinc on lipid metabolism indices Herzig,(2009) proved that these was a significant decrease of plasma cholesterol on administration of high amount of zinc Aksu (2010) also reported the decrease of total and LDL, combined with the increase in HDL in chickens blood plasma, when the feed was supplemented with organic complexes of zinc, copper and manganese. However, Kucuk,(2008) did not confirm any significant changes in the concentration of total cholesterol triglycerides and glucose when supplementing $30 \mathrm{mg}$ of zinc per $\mathrm{kg}$ of feed mixture

The ALP level in the serum of zinc supplemented birds was found to be significantly different $(\mathrm{p} \leq 0.05)$ (Table 10) from control. Idowu, (2011) also observed significant difference in the levels of ALP between control and zinc proteinate group with higher levels in zinc proteinate that due to zinc binding capacity of serum alkaline phosphate act as good indicator of zinc status. The increase in ALP level on zinc supplementation might be due to increase in corticosteroid hormone secretion epinephrine and nonepinephrine. (Al-doraji and Amein 2011). In contrast to this non significant level of serum ALP in organic fed groups was reported by (Parak and Strakova 2011). Anshan, (1990) found significant increase of blood plasma ALP activity in association with increase of dietary zinc level

MDA (Table (12) is widely used as an indicator for lipid peroxidation which is the most oxidative stress reaction Woo,(2006). Our results are in agreement with the previous studies Aksu (2010) where zinc and manganese proteinate chelate supplementation decreased plasma level of MDA as compared to inorganic minerals

Zinc proteinate chelate showed higher SOD (Table (12 ).Zinc play an important role in immunomodulation by increasing the thymocyte and peripheral T-cell counts and interferon production, which were perhaps responsible for elevated humoral immune response Halliwell,(1993). In our study. The combination of organic zinc and manganese complemented the functional activity of superoxide dismutase, which is vital for the integrity of macrophage and heterophils that are responsible for elevating the antibody titers Wellenghausem 1997 carcass characteristics 


\section{zinc chelate-Mn chelate- blood profile-carcass traits- immune response}

The carcass characteristics, dressing percentage and organs weight are presented in tables (13-15).

\section{Dressing percentage}

There was significant difference in dressing percentage with supplementation of organic $\mathrm{Zn}$ and $\mathrm{Mn}$. Our finding are in contrast with that of Ellen.(2012) who found that dressing percentage was significantly higher in group fed with amino acid chelate of $\mathrm{Cu}, \mathrm{Mn}, \mathrm{Zn}$ and $\mathrm{Fe}$ respectively and contrary to Viladimir,(2010) who found that groups fed with trace elements in proteinated form had no effect on carcass yield

\section{Organ weights}

The results of the present study showed that there was no significant $(\mathrm{P} \leq 0.05)$ effect of supplementation of inorganic and organic source of $\mathrm{Mn}$ and $\mathrm{Zn}$ on relative weight of liver ,heart, gizzard and spleen but significantly( $\mathrm{P} \leq 0.05)$, higher liver, heart and gizzard were observed with zinc proteinate chelate . The present finding was in accordance with that of (Osman and Ragab 2007) who reported that broiler chicks fed with diets supplemented with $\mathrm{Zn}$ tryptophan had the highest gizzard percentage Yang ,(2011) observed that supplementation of traces minerals to basal broiler had no significant effect on relative weights of spleen. This finding was contrary to Iqbal ,(2011), this may be due to nutrients repartitioning to develop body weight and the immune system needs a relatively small amount of nutrients in relation to what is needed for growth (Barlett and smith, 2003).

\section{CONCLUSION}

It is concluded that supplementing diets of group Japanese quail with $\mathrm{Mn}$ and $\mathrm{Zn}$ chelate especially $\mathrm{Mn}$ and $\mathrm{Zn}$ proteinated chelate had great influence on performance, growth, blood profile and carcass characteristic and improved the immune response 
Ghada Mostafa El ashry

Table (1):Composition and chemical analysis of experimental diets of growing quails ingredients (\%)

\begin{tabular}{|l|l|}
\hline Ingredients & $\begin{array}{l}\text { Experimental diet } \\
\text { 3-6 weeks }\end{array}$ \\
\hline Yellow corn & 55.6 \\
Soybean meal & 32.4 \\
Protein concentration $^{*}$ & 10.0 \\
Oil & 1.1 \\
Bone meal & - \\
Limestone $_{\text {Sodium bicarbonate }}$ & - \\
Sodium chloride $^{*}$ & 0.3 \\
Premix $^{* *}$ & 0.3 \\
\hline
\end{tabular}

Calculated analysis:

\begin{tabular}{l|l} 
Crude protein $(\%)$ & 24.6
\end{tabular}

$\mathrm{ME}(\mathrm{Kcal} / \mathrm{kg}) \quad 2902$

$\mathrm{C} / \mathrm{P}$ (ratio) $\quad 118$

Crude fat $(\%) \quad 2.65$

Crude fiber $(\%) \quad 3.35$

Calcium (\%) 0.96

Phosphorus available (\%) $\quad 0.51$

Methionine (\%) 0.49

\begin{tabular}{l|l} 
Cystine (\%) & 0.39
\end{tabular}

Lysin $(\%) \quad 1.34$

Arginine (\%) 1.63

Linoleic acid $(\%) \quad 1.18$

$*$ = Broiler concentrate contained 52\% CP.

**= each kg contain vit. A (12M.I.U.), vit. $\mathrm{D}_{3}$ (2M.I.U.), vit E (10g), vit. $\mathrm{K}_{2}(1 \mathrm{~g})$, vit. $\mathrm{B}_{1}(1 \mathrm{~g})$, vit. $\mathrm{B}_{2}(4 \mathrm{~g})$, vit. $\mathrm{B}_{6}(1.5 \mathrm{~g})$, vit. $\mathrm{B}_{12}(10 \mathrm{~g})$, Pantathenic acid (10g), Nicotinic acid (20g), Folicacid (1000 mg), Biotin (50g), Choline chloride (500g), Copper (10g), Iodine (1g), Iron (30g), Manganese (55g), Zinc (55g), Selenium (0.1g). 
zinc chelate-Mn chelate- blood profile-carcass traits- immune response

Table (2): Means \pm standard error of live body weight (g) of Japanese quail fed diets with different sources of zinc and manganese.

\begin{tabular}{|l|c|c|c|c|c|}
\hline \multirow{2}{*}{ Treatments } & \multicolumn{6}{|c|}{ Live body weight (g) (LBW) } \\
\cline { 2 - 6 } & $\mathbf{2} \mathbf{~ w k}$ & $\mathbf{3} \mathbf{~ w k}$ & $\mathbf{4} \mathbf{w k}$ & $\mathbf{5 ~ w k}$ & $\mathbf{6} \mathbf{w k}$ \\
\hline T1 & $72.35 \pm 0.37^{\mathrm{b}}$ & $120.95 \pm 0.57^{\mathrm{b}}$ & $172.30 \pm 0.52^{\mathrm{b}}$ & $198.94 \pm 0.42^{\mathrm{b}}$ & $257.83 \pm 0.25^{\mathrm{b}}$ \\
T2 & $76.80 \pm 0.25^{\mathrm{ab}}$ & $128.95 \pm 0.67^{\mathrm{ab}}$ & $178.75 \pm 0.63^{\mathrm{ab}}$ & $221.15 \pm 0.51^{\mathrm{ab}}$ & $272.22 \pm 0.29^{\mathrm{ab}}$ \\
T3 & $78.55 \pm 0.43^{\mathrm{a}}$ & $135.10 \pm 0.54^{\mathrm{a}}$ & $180.05 \pm 0.89^{\mathrm{ab}}$ & $225.20 \pm 0.54^{\mathrm{a}}$ & $276.17 \pm 0.26^{\mathrm{a}}$ \\
T4 & $77.75 \pm 0.52^{\mathrm{ab}}$ & $127.75 \pm 0.54^{\mathrm{ab}}$ & $178.60 \pm 0.58^{\mathrm{ab}}$ & $219.85 \pm 0.55^{\mathrm{ab}}$ & $269.72 \pm 0.25^{\mathrm{ab}}$ \\
T5 & $79.80 \pm 0.39^{\mathrm{a}}$ & $136.20 \pm 0.66^{\mathrm{a}}$ & $182.45 \pm 0.46^{\mathrm{a}}$ & $224.60 \pm 0.54^{\mathrm{a}}$ & $278.47 \pm 0.24^{\mathrm{a}}$ \\
P value & 0.050 & 0.054 & 0.051 & 0.054 & 0.045 \\
Sig. & $*$ & $*$ & $*$ & $*$ & $*$ \\
\hline
\end{tabular}

$*=$ Significant at $\mathrm{P} \leq 0.05 \quad \mathrm{~N} . \mathrm{S}=$ not significant

Different letters $(\mathrm{a}-\mathrm{b})$ in the same column indicate significant differences $(\mathrm{P} \leq 0.05)$

(T1) fed basal diet without any supplementation (control), (T2) basal diet +zinc tryptophan chelate

(T3) basal diet + zinc proteinate chelate , (T4) basal diet+manganese tryptophane chelate, (T5)

basal diet+manganese proteinate chelate.

Table (3): Means \pm standard error of live body weight gain (g) of Japanese quail fed diets with different levels of zinc and manganese.

\begin{tabular}{|l|c|c|c|}
\hline \multirow{2}{*}{ Treatments } & \multicolumn{3}{|c|}{ Live body weight gain (g) (LBWG) } \\
\cline { 2 - 4 } & LBWG 2-4 & LBWG 4-6 & LBWG 2-6 \\
\hline T1 & $99.924 \pm 0.98$ & $85.64 \pm 0.79^{\mathrm{b}}$ & $186.01 \pm 0.55^{\mathrm{b}}$ \\
T2 & $102.05 \pm 1.78$ & $93.40 \pm 1.36^{\mathrm{ab}}$ & $195.11 \pm 0.54^{\mathrm{ab}}$ \\
$\mathrm{T} 3$ & $101.50 \pm 0.81$ & $96.15 \pm 0.45^{\mathrm{a}}$ & $198.02 \pm 0.45^{\mathrm{a}}$ \\
$\mathrm{T} 4$ & $100.85 \pm 1.25$ & $91.25 \pm 1.77^{\mathrm{ab}}$ & $192.01 \pm 0.44^{\mathrm{ab}}$ \\
T5 & $102.65 \pm 1.26$ & $96.15 \pm 41.55^{\mathrm{a}}$ & $199.10 \pm 0.56^{\mathrm{a}}$ \\
P value & 0.510 & 0.054 & 0.315 \\
Sig. & $*$ & $*$ & $*$ \\
\hline
\end{tabular}

$*=$ Significant at $\mathrm{P} \leq 0.05$

$\mathrm{N} . \mathrm{S}=$ not significant

Different letters $(\mathrm{a}-\mathrm{b})$ in the same column indicate significant differences $(\mathrm{P} \leq 0.05)$

(T1) fed basal diet without any supplementation (control), (T2) basal diet +zinc tryptophane chelate (T3) basal diet + zinc proteinate chelate , (T4) basal diet+manganese tryptophane chelate , (T5) basal diet+manganese proteinate chelate. 
Ghada Mostafa El ashry

Table (4): Means \pm standard error of feed consumption (g feed / bird/week) of Japanese quail fed diets with different levels of zinc and manganese.

\begin{tabular}{|l|c|c|c|}
\hline \multirow{2}{*}{ Treatments } & \multicolumn{3}{|c|}{ Feed consumption (g feed / bird/ week) (FC) } \\
\cline { 2 - 4 } & FC 2-4wk & FC 4-6wk & FC 2-6wk \\
\hline T1 & $252.88 \pm 7.12$ & $306.25 \pm 12.12^{\mathrm{b}}$ & $559.13 \pm 14.66$ \\
T2 & $255.75 \pm 8.01$ & $301.25 \pm 11.78^{\mathrm{ab}}$ & $557.00 \pm 14.79$ \\
T3 & $251.00 \pm 7.89$ & $321.63 \pm 10.12^{\mathrm{a}}$ & $572.63 \pm 7.67$ \\
T4 & $253.88 \pm 8.88$ & $301.88 \pm 13.15^{\mathrm{ab}}$ & $555.75 \pm 9.55$ \\
T5 & $260.13 \pm 9.14$ & $321.13 \pm 12.01^{\mathrm{a}}$ & $581.25 \pm 11.77$ \\
P value & 0.802 & 0.052 & 0.192 \\
Sig. & $\mathrm{NS}$ & $*$ & $\mathrm{NS}$ \\
\hline
\end{tabular}

*= Significant at $\mathrm{P} \leq 0.05 \quad \mathrm{~N} . \mathrm{S}=$ not significant

Different letters $(a-b)$ in the same column indicate significant differences $(\mathrm{P} \leq 0.05)$

(T1) fed basal diet without any supplementation (control), (T2) basal diet +zinc tryptophane chelate (T3) basal diet + zinc proteinate chelate , (T4) basal diet+manganese tryptophane chelate , (T5) basal diet+manganese proteinate chelate.

Table (5): Means \pm standard error of feed conversion ratio ( $\mathrm{g}$ feed/ $\mathrm{g}$ body weight gain) of Japanese quail fed diets with different levels of zinc and manganese.

\begin{tabular}{|l|c|c|c|}
\hline \multirow{2}{*}{ Treatments } & \multicolumn{3}{|c|}{ Feed conversion (g feed/ g body weight gain) (FCR) } \\
\cline { 2 - 4 } & FCR 2-4wk & FCR 4-6wk & FCR 2-6wk \\
\hline T1 & $2.56 \pm 1.11$ & $3.62 \pm 0.78^{\mathrm{b}}$ & $3.03 \pm 0.55$ \\
T2 & $2.52 \pm 1.54$ & $3.38 \pm 0.88^{\mathrm{ab}}$ & $2.90 \pm 0.44$ \\
T3 & $2.51 \pm 1.22$ & $3.35 \pm 0.77^{\mathrm{ab}}$ & $2.91 \pm 0.01$ \\
T4 & $2.53 \pm 1.65$ & $3.42 \pm 0.87^{\mathrm{a}}$ & $2.89 \pm 0.45$ \\
T5 & $2.54 \pm 1.63$ & $3.43 \pm 0.65^{\mathrm{a}}$ & $2.93 \pm 0.04$ \\
P value & 0.572 & 0.053 & 0.672 \\
Sig. & $\mathrm{NS}$ & $*$ & $\mathrm{NS}$ \\
\hline \hline
\end{tabular}

*= Significant at $\mathrm{P} \leq 0.05 \quad$ N.S $=$ not significant

Different letters $(\mathrm{a}-\mathrm{b})$ in the same column indicate significant differences $(\mathrm{P} \leq 0.05)$

(T1) fed basal diet without any supplementation (control), (T2) basal diet +zinc tryptophane chelate (T3) basal diet + zinc proteinate chelate, (T4) basal diet+manganese tryptophane chelate , (T5) basal diet+manganese proteinate chelate. 
zinc chelate-Mn chelate- blood profile-carcass traits- immune response

Table (6): Means \pm standard error of hematological characteristics of Japanese quail fed diets with different levels of zinc and manganese.

\begin{tabular}{|l|c|c|c|}
\hline Treatments & \multicolumn{3}{|c|}{ Hematological characteristics } \\
\hline & RBC's (10\%/cmm) & Hb (g/dl) & PCV \% \\
\hline T1 & $2.74 \pm 0.07$ & $10.92 \pm 0.72$ & $29.2 \pm 0.54^{\mathrm{c}}$ \\
T2 & $3.03 \pm 0.19$ & $12.78 \pm 0.49$ & $33.0 \pm 0.74^{\mathrm{ab}}$ \\
T3 & $3.13 \pm 0.05$ & $13.30 \pm 0.24$ & $34.8 \pm 2.76^{\mathrm{ab}}$ \\
T4 & $3.09 \pm 0.07$ & $12.85 \pm 0.28$ & $32.8 \pm 0.54^{\mathrm{b}}$ \\
T5 & $3.12 \pm 0.18$ & $13.27 \pm 0.42$ & $35.1 \pm 1.18^{\mathrm{a}}$ \\
P value & 0.676 & 0.314 & 0.053 \\
Sig. & $\mathrm{NS}$ & $\mathrm{NS}$ & $*$ \\
\hline
\end{tabular}

*= Significant at $\mathrm{P} \leq 0.05 \quad \mathrm{~N} . \mathrm{S}=$ not significant

Different letters $(\mathrm{a}-\mathrm{b})$ in the same column indicate significant differences $(\mathrm{P} \leq 0.05)$

(T1) fed basal diet without any supplementation (control), (T2) basal diet +zinc tryptophan chelate

(T3) basal diet + zinc proteinate chelate , (T4) basal diet+manganese tryptophane chelate , (T5) basal diet+manganese proteinate chelate.

Table (7): Means \pm standard error of hematological characteristics of Japanese quail fed diets with different levels of zinc and manganese.

\begin{tabular}{|l|c|c|c|c|c|}
\hline Treatments & \multicolumn{5}{|c|}{ Hematological characteristics } \\
\hline & $\begin{array}{c}\text { WBC's } \\
\left(\mathbf{1 0} / \mathbf{c m m}^{\prime}\right)\end{array}$ & $\begin{array}{c}\text { Lymphocyte } \\
\text { \% }\end{array}$ & $\begin{array}{c}\text { Heterophils } \\
\text { \% }\end{array}$ & H/L & $\begin{array}{c}\text { Monocyte } \\
\text { \% }\end{array}$ \\
\hline T1 & $10.07 \pm 0.29$ & $35.78 \pm 0.91^{\mathrm{b}}$ & $51.12 \pm 1.88^{\mathrm{a}}$ & $1.43 \pm 0.05^{\mathrm{a}}$ & $8.68 \pm 0.17$ \\
T2 & $11.80 \pm 0.75$ & $42.09 \pm 1.93^{\mathrm{ab}}$ & $45.68 \pm 1.06^{\mathrm{ab}}$ & $1.10 \pm 0.08^{\mathrm{ab}}$ & $8.25 \pm 0.12$ \\
T3 & $12.12 \pm 0.22$ & $44.24 \pm 2.19^{\mathrm{a}}$ & $44.18 \pm 2.19^{\mathrm{ab}}$ & $1.00 \pm 0.01^{\mathrm{b}}$ & $8.33 \pm 0.34$ \\
T4 & $11.77 \pm 0.29$ & $40.21 \pm 1.06^{\mathrm{ab}}$ & $43.82 \pm 0.88^{\mathrm{b}}$ & $1.09 \pm 0.04^{\mathrm{ab}}$ & $8.11 \pm 0.10$ \\
T5 & $11.98 \pm 0.74$ & $42.05 \pm 1.88^{\mathrm{ab}}$ & $45.12 \pm 2.19^{\mathrm{ab}}$ & $1.09 \pm 0.09^{\mathrm{ab}}$ & $8.10 \pm 0.31$ \\
P value & 0.743 & 0.033 & 0.010 & 0.016 & 0.599 \\
Sig. & $\mathrm{NS}$ & $*$ & $* *$ & $* *$ & $\mathrm{NS}$ \\
\hline \hline
\end{tabular}

$*=$ Significant at $\mathrm{P} \leq 0.05 \quad \mathrm{~N} . \mathrm{S}=$ not significant

Different letters $(\mathrm{a}-\mathrm{b})$ in the same column indicate significant differences $(\mathrm{P} \leq 0.05)$

(T1) fed basal diet without any supplementation (control), (T2) basal diet +zinc tryptophane chelate

(T3) basal diet + zinc proteinate chelate, (T4) basal diet+manganese tryptophane chelate, (T5) basal diet+manganese proteinate chelate. 
Ghada Mostafa El ashry

Table (8): Means \pm standard error of protein profile (g/dl) of Japanese quail fed diets with different levels of zinc and manganese.

\begin{tabular}{|l|c|c|c|c|}
\hline \multicolumn{1}{c}{$\begin{array}{c}\text { Dietary } \\
\text { supplementations }\end{array}$} & \multicolumn{4}{|c|}{ Protein profile (g/dl) } \\
\hline & Total protein & Albumin & Globulin & A/G ratio \\
\hline T1 & $3.26 \pm 0.20$ & $1.94 \pm 0.011^{\mathrm{b}}$ & $1.32 \pm 0.05$ & $1.56 \pm 0.17$ \\
T2 & $3.71 \pm 0.14$ & $2.27 \pm 0.05^{\mathrm{ab}}$ & $1.44 \pm 0.11$ & $1.71 \pm 0.17$ \\
T3 & $3.85 \pm 0.06$ & $2.32 \pm 0.10^{\mathrm{a}}$ & $1.53 \pm 0.12$ & $1.60 \pm 0.14$ \\
T4 & $3.66 \pm 0.10$ & $2.31 \pm 0.05^{\mathrm{a}}$ & $1.35 \pm 0.10$ & $1.82 \pm 0.10$ \\
T5 & $3.74 \pm 0.17$ & $2.40 \pm 0.10^{\mathrm{a}}$ & $1.34 \pm 0.05$ & $1.94 \pm 0.14$ \\
P value & 0.107 & 0.005 & 0.592 & 0.607 \\
Sig. & $\mathrm{NS}$ & $* *$ & $\mathrm{NS}$ & $\mathrm{Ns}$ \\
\hline \hline
\end{tabular}

$*=$ Significant at $\mathrm{P} \leq 0.05 \quad \mathrm{~N} . \mathrm{S}=$ not significant

Different letters $(\mathrm{a}-\mathrm{b})$ in the same column indicate significant differences $(\mathrm{P} \leq 0.05)$

(T1) fed basal diet without any supplementation (control), (T2) basal diet +zinc tryptophane chelate (T3) basal diet + zinc proteinate chelate , (T4) basal diet+manganese tryptophane chelate , (T5) basal diet+manganese proteinate chelate.

Table (9): Means \pm standard error of lipids profile $(\mathrm{mg} / \mathrm{dl})$ of Japanese quail fed diets with different levels of zinc and manganese.

\begin{tabular}{|l|c|c|c|c|c|}
\hline Treatments & \multicolumn{5}{|c|}{ Lipids profile (mg/dl) } \\
\hline & Total lipids & Cholesterol & Triglyceride & LDL & HDL \\
\hline T1 & $305.18 \pm 6.92$ & $125.36 \pm 5.34$ & $100.27 \pm 6.06^{\mathrm{a}}$ & $36.10 \pm 1.47^{\mathrm{a}}$ & $42.84 \pm 3.18^{\mathrm{b}}$ \\
T2 & $268.80 \pm 14.71$ & $94.07 \pm 4.24$ & $81.42 \pm 3.28^{\mathrm{ab}}$ & $27.81 \pm 4.78^{\mathrm{b}}$ & $54.25 \pm 1.11^{\mathrm{ab}}$ \\
T3 & $270.26 \pm 2.47$ & $85.62 \pm 4.62$ & $77.77 \pm 4.60^{\mathrm{b}}$ & $23.10 \pm 1.06^{\mathrm{c}}$ & $61.51 \pm 1.95^{\mathrm{a}}$ \\
T4 & $272.23 \pm 18.82$ & $96.65 \pm 6.12$ & $80.23 \pm 3.85^{\mathrm{ab}}$ & $30.19 \pm 3.19^{\mathrm{ab}}$ & $53.04 \pm 1.90^{\mathrm{ab}}$ \\
T5 & $265.70 \pm 7.73$ & $88.13 \pm 7.18$ & $74.37 \pm 5.47^{\mathrm{b}}$ & $25.52 \pm 2.0^{\mathrm{bc}}$ & $51.09 \pm 2.88^{\mathrm{ab}}$ \\
P value & 0.511 & 0.334 & 0.035 & 0.032 & 0.051 \\
Sig. & NS & NS & $*$ & $*$ & $*$ \\
\hline \hline
\end{tabular}

$*=$ Significant at $\mathrm{P} \leq 0.05$

N.S $=$ not significant

Different letters $(\mathrm{a}-\mathrm{b})$ in the same column indicate significant differences $(\mathrm{P} \leq 0.05)$

(T1) fed basal diet without any supplementation (control), (T2) basal diet +zinc tryptophane chelate (T3) basal diet + zinc proteinate chelate, (T4) basal diet+manganese tryptophane chelate, (T5) basal diet+manganese proteinate chelate. 
zinc chelate-Mn chelate- blood profile-carcass traits- immune response

Table (10 ): Means \pm standard error of liver and kidney functions of Japanese quail fed diets with different levels of zinc and manganese.

\begin{tabular}{|l|c|c|c|c|c|}
\hline \multirow{2}{*}{ Treatments } & \multicolumn{5}{|c|}{ Liver and kidney functions } \\
\cline { 2 - 6 } & AST (U/L) & ALT (U/L) & ALP (U/L) & $\begin{array}{c}\text { Creatinine } \\
\text { (mg/dl) }\end{array}$ & $\begin{array}{c}\text { Uric acid } \\
\text { (mg/dl) }\end{array}$ \\
\hline T1 & & & $1.01 \pm 0.09$ & $2.87 \pm 0.08$ \\
T2 & $22.78 \pm 0.68^{\mathrm{ab}}$ & $49.63 \pm 2.07^{\mathrm{ab}}$ & $119.56 \pm 2.00^{\mathrm{b}}$ & $0.83 \pm 0.16$ & $2.45 \pm 0.15$ \\
$\mathrm{~T} 3$ & $21.74 \pm 0.63^{\mathrm{b}}$ & $48.61 \pm 1.55^{\mathrm{b}}$ & $124.11 \pm 5.29^{\mathrm{ab}}$ & 0.16 & $2.30 \pm 0.18$ \\
$\mathrm{~T} 4$ & $24.15 \pm 0.58^{\mathrm{a}}$ & $52.47 \pm 1.39^{\mathrm{a}}$ & $136.02 \pm 2.88^{\mathrm{a}}$ & $0.91 \pm 0.08$ & $2.53 \pm 0.10$ \\
T5 & $22.67 \pm 0.40^{\mathrm{ab}}$ & $48.69 \pm 1.36^{\mathrm{b}}$ & $129.64 \pm 1.92^{\mathrm{ab}}$ & $0.89 \pm 0.07$ & $2.39 \pm 0.15$ \\
P value & $23.30 \pm 1.03^{\mathrm{a}}$ & $53.14 \pm 1.32^{\mathrm{a}}$ & $139.18 \pm 4.62^{\mathrm{a}}$ & $0.90 \pm 0.08$ & 0.117 \\
Sig. & 0.001 & 0.037 & 0.004 & 0.968 & $\mathrm{NS}$ \\
\hline
\end{tabular}

*= Significant at $\mathrm{P} \leq 0.05 \quad \mathrm{~N} . \mathrm{S}=$ not significant

Different letters $(\mathrm{a}-\mathrm{b})$ in the same column indicate significant differences $(\mathrm{P} \leq 0.05)$

(T1) fed basal diet without any supplementation (control), (T2) basal diet +zinc tryptophane chelate (T3) basal diet + zinc proteinate chelate , (T4) basal diet+manganese tryptophane chelate , (T5) basal diet+manganese proteinate chelate.

Table (11): Means \pm standard error of glucose, triodothyronine (T3), calcium and inorganic phosphorus of Japanese quail fed diets with different levels of zinc and manganese.

\begin{tabular}{|l|c|c|c|c|}
\hline Treatments & \multicolumn{4}{|c|}{ Blood biochemical parameters } \\
\hline & $\begin{array}{c}\text { Glucose } \\
(\mathbf{m g} / \mathbf{d l})\end{array}$ & T3 $(\mathbf{n g} / \mathbf{d l})$ & Ca $(\mathbf{m g} / \mathbf{d l})$ & IP (mg/dl) \\
\hline T1 & $177.67 \pm 7.99$ & $4.07 \pm 0.30$ & $11.18 \pm 0.12^{\mathrm{b}}$ & $6.10 \pm 0.26$ \\
T2 & $164.20 \pm 6.37$ & $4.63 \pm 0.30$ & $13.92 \pm 0.22^{\mathrm{ab}}$ & $6.95 \pm 0.40$ \\
T3 & $160.31 \pm 2.81$ & $4.76 \pm 0.22$ & $14.16 \pm 0.25^{\mathrm{a}}$ & $6.90 \pm 0.37$ \\
T4 & $166.90 \pm 7.26$ & $4.50 \pm 0.30$ & $13.78 \pm 0.22^{\mathrm{ab}}$ & $6.80 \pm 0.44$ \\
T5 & $163.12 \pm 7.28$ & $4.67 \pm 0.28$ & $13.98 \pm 0.12^{\mathrm{ab}}$ & $6.72 \pm 0.52$ \\
P value & 0.581 & 0.801 & 0.051 & 0.877 \\
Sig. & $\mathrm{NS}$ & $\mathrm{NS}$ & $*$ & $\mathrm{NS}$ \\
\hline
\end{tabular}

$*=$ Significant at $\mathrm{P} \leq 0.05 \quad \mathrm{~N} . \mathrm{S}=$ not significant

Different letters $(\mathrm{a}-\mathrm{b})$ in the same column indicate significant differences $(\mathrm{P} \leq 0.05)(\mathrm{T} 1)$ fed basal diet without any supplementation (control), (T2) basal diet +zinc tryptophane chelate (T3) basal diet + zinc proteinate chelate , (T4) basal diet+manganese tryptophane chelate, (T5) basal diet+manganese proteinate chelate. 
Table (12): Means \pm standard error of indicators of antioxidative status in blood parameters of Japanese quail fed diets with different levels of zinc and manganese.

\begin{tabular}{|l|c|c|c|c|}
\hline Treatments & \multicolumn{3}{|c|}{ Indicators of antioxidative status in blood } \\
\hline & MDA $(\boldsymbol{\mu m o l} / \mathbf{L})$ & TAC $(\mathbf{n m o l} / \mathbf{L})$ & $\begin{array}{c}\text { GSH-Px } \\
(\mathbf{m m o l} / \mathbf{L})\end{array}$ & SOD (U/ml) \\
\hline T1 & $12.15 \pm 0.31$ & $0.61 \pm 0.05$ & $42.20 \pm 2.05^{\mathrm{b}}$ & $58.54 \pm 2.12$ \\
T2 & $10.28 \pm 0.35$ & $0.84 \pm 0.01$ & $51.00 \pm 2.32^{\mathrm{a}}$ & $70.96 \pm 2.21$ \\
T3 & $9.93 \pm 0.34$ & $0.90 \pm 0.40$ & $52.78 \pm 1.26^{\mathrm{a}}$ & $73.78 \pm 2.55$ \\
T4 & $10.51 \pm 0.45$ & $0.75 \pm 0.20$ & $50.32 \pm 2.05^{\mathrm{ab}}$ & $64.58 \pm 2.45$ \\
T5 & $10.14 \pm 0.42$ & $0.83 \pm 0.02$ & $49.55 \pm 0.82^{\mathrm{ab}}$ & $67.06 \pm 2.33$ \\
P value & 0.144 & 0.067 & 0.003 & 0.148 \\
Sig. & $\mathrm{NS}$ & $\mathrm{NS}$ & $* *$ & $\mathrm{NS}$ \\
\hline
\end{tabular}

*= Significant at $\mathrm{P} \leq 0.05 \quad$ N.S $=$ not significant

Different letters $(\mathrm{a}-\mathrm{b})$ in the same column indicate significant differences $(\mathrm{P} \leq 0.05)(\mathrm{T} 1)$ fed basal diet without any supplementation (control), (T2) basal diet +zinc tryptophane chelate (T3) basal diet + zinc proteinate chelate, (T4) basal diet+manganese tryptophan chelate, (T5) basal diet+manganese proteinate chelate.

Table (13): Means \pm standard error of some carcass traits (\%)of Japanese quail fed diets with different chelates of zinc and manganese.

\begin{tabular}{|l|c|c|c|c|}
\hline Treatments & \multicolumn{4}{|c|}{ Carcass traits } \\
\hline & Pre-slaughter $(\mathbf{g})$ & Carcass $(\%)$ & Dressing (\%) & Spleen (\%) \\
\hline T1 & $257.00 \pm 4.59^{\mathrm{b}}$ & $54.04 \pm 0.42^{\mathrm{b}}$ & $57.77 \pm 0.48^{\mathrm{b}}$ & $0.05 \pm 0.01^{\mathrm{b}}$ \\
T2 & $272.10 \pm 5.80^{\mathrm{ab}}$ & $55.51 \pm 0.61^{\mathrm{ab}}$ & $59.73 \pm 0.70^{\mathrm{ab}}$ & $0.06 \pm 0.02^{\mathrm{ab}}$ \\
T3 & $277.90 \pm 4.40^{\mathrm{a}}$ & $60.24 \pm 0.50^{\mathrm{a}}$ & $64.58 \pm 0.54^{\mathrm{a}}$ & $0.06 \pm 0.02^{\mathrm{ab}}$ \\
T4 & $269.60 \pm 5.99^{\mathrm{ab}}$ & $53.88 \pm 0.63^{\mathrm{ab}}$ & $58.01 \pm 0.61^{\mathrm{ab}}$ & $0.07 \pm 0.01^{\mathrm{ab}}$ \\
T5 & $278.30 \pm 9.59^{\mathrm{a}}$ & $59.34 \pm 1.42^{\mathrm{ab}}$ & $63.56 \pm 1.41^{\mathrm{a}}$ & $0.08 \pm 0.01^{\mathrm{a}}$ \\
P value & 0.011 & 0.027 & 0.012 & 0.054 \\
Sig. & $* *$ & $*$ & $* *$ & $*$ \\
\hline
\end{tabular}

$*=$ Significant at $\mathrm{P} \leq 0.05 \quad \mathrm{~N} . \mathrm{S}=$ not significant

Different letters $(\mathrm{a}-\mathrm{b})$ in the same column indicate significant differences $(\mathrm{P} \leq 0.05)$

(T1) fed basal diet without any supplementation (control), (T2) basal diet +zinc tryptophane chelate (T3) basal diet + zinc proteinate chelate , (T4) basal diet+manganese tryptophane chelate , (T5) basal diet+manganese proteinate chelate. 
zinc chelate-Mn chelate- blood profile-carcass traits- immune response

Table (14): Means \pm standard error of some carcass traits (\%) of Japanese quail fed diets with different levels of zinc and manganese.

\begin{tabular}{|l|c|c|c|c|}
\hline Treatments & \multicolumn{4}{|c|}{ Carcass traits } \\
\hline & Pancreas (\%) & Liver (\%) & Heart (\%) & Gizzard (\%) \\
\hline T1 & $0.29 \pm 0.02$ & $1.65 \pm 0.09$ & $0.58 \pm 0.02^{\mathrm{b}}$ & $1.49 \pm 0.04^{\mathrm{b}}$ \\
T2 & $0.24 \pm 0.01$ & $1.80 \pm 0.09$ & $0.64 \pm 0.03^{\mathrm{ab}}$ & $1.77 \pm 0.08^{\mathrm{a}}$ \\
T3 & $0.21 \pm 0.01$ & $1.86 \pm 0.04$ & $0.66 \pm 0.02^{\mathrm{a}}$ & $1.82 \pm 0.07^{\mathrm{a}}$ \\
T4 & $0.25 \pm 0.01$ & $1.76 \pm 0.08$ & $0.64 \pm 0.02^{\mathrm{ab}}$ & $1.73 \pm 0.03^{\mathrm{a}}$ \\
T5 & $0.24 \pm 0.03$ & $1.81 \pm 0.12$ & $0.63 \pm 0.03^{\mathrm{ab}}$ & $1.78 \pm 0.09^{\mathrm{a}}$ \\
P value & 0.251 & 0.792 & 0.011 & 0.052 \\
Sig. & NS & NS & $* *$ & $*$ \\
\hline \hline
\end{tabular}

$*=$ Significant at $\mathrm{P} \leq 0.05 \quad \mathrm{~N} . \mathrm{S}=$ not significant

Different letters $(a-b)$ in the same column indicate significant differences $(\mathrm{P} \leq 0.05)$

(T1) fed basal diet without any supplementation (control), (T2) basal diet +zinc tryptophan chelate

(T3) basal diet + zinc proteinate chelate , (T4) basal diet+manganese tryptophane chelate , (T5)

basal diet+manganese proteinate chelate.

Table (15): Means \pm standard error of some carcass traits (\%)of Japanese quail fed diets with different levels of zinc and manganese.

\begin{tabular}{|l|l|l|l|l|}
\hline Treatments & \multicolumn{4}{|c|}{ Carcass traits } \\
\hline & \multicolumn{1}{|c|}{ Intestine \% } & \multicolumn{1}{|c|}{ Intestinal (cm) } & \multicolumn{1}{|c|}{ Cecum (\%) } & Cecum (cm) \\
\hline T1 & $3.03 \pm 0.14$ & $63.70 \pm 1.94$ & $0.45 \pm 0.05$ & $7.91 \pm 0.29$ \\
T2 & $3.22 \pm 0.15$ & $68.10 \pm 1.18$ & $0.53 \pm 0.02$ & $9.14 \pm 0.38$ \\
T3 & $3.35 \pm 0.12$ & $70.80 \pm 2.76$ & $0.58 \pm 0.04$ & $9.59 \pm 0.39$ \\
T4 & $3.17 \pm 0.09$ & $66.50 \pm 3.09$ & $0.51 \pm 0.05$ & $8.39 \pm 0.54$ \\
T5 & $3.29 \pm 0.20$ & $67.60 \pm 2.69$ & $0.56 \pm 0.03$ & $9.46 \pm 0.70$ \\
P value & 0.524 & 0.349 & 0.345 & 0.314 \\
Sig. & NS & NS & NS & NS \\
\hline \hline
\end{tabular}

$*=$ Significant at $\mathrm{P} \leq 0.05 \quad \mathrm{~N} . \mathrm{S}=$ not significant

Different letters $(\mathrm{a}-\mathrm{b})$ in the same column indicate significant differences $(\mathrm{P} \leq 0.05)$

(T1) fed basal diet without any supplementation (control), (T2) basal diet +zinc tryptophane chelate (T3) basal diet + zinc proteinate chelate , (T4) basal diet+manganese tryptophane chelate , (T5) basal diet+manganese proteinate chelate.

\section{REFERENCES}

Abdallah, A. G., El-Husseiny O. M. and Abdel-Latif, K. O. 2009. Influence of some dietary organic mineral supplementations on broiler performance International Journal of Poultry Science 8 (3): 291-98.

Aksu, D. S., Taylan, A. and Bülent O. 2010. The effects of lower supplementation levels of organically complexed minerals (zinc, copper and manganese) versus inorganic forms on hematological and biochemical parameters in broilers. Kafkas Univ Vet Fak Derg., 16 (4): 553-559.

Al-Daraji, H. J. and Amen, M. H. M. 2011. Effect of dietary zinc on certain blood traits of broiler breeder chickens. 
Ghada Mostafa El ashry

International Journal of Poultry Science 10 (10): 807-13.

Anshan, S., An, W. and Zhenying, X. 1990. Effects of dietary zinc and calcium level on performance, blood biochemical parameter and zinc content in.tissues of the layer. Chinese J. Anim. Vet. Sci., 4.(Abstr.).

Bartlett JR and Smith MO 2003. Effects of different levels of zinc on the erformance and immuno competence of broilers under heat stress. Poultry Science, 82:1580- 1588.

Bauer, J.D. 1982. Clinical laboratory methods, 9th edition, pp. 580-581.CV Mosby Co, USA.

Brown, L. and Pentland S., 2007. Health infertility of diet on the hematology and serum biochemistryorganization: Male infertility - improving sperm., quality. Acubalance Wellness. Centre Ltd. Onwest . 8th Ave. in Vancouver Bc. Canada.

Buchi, G. 1974. Stereoactive synthesis of alpha-sinensal. Journal of the American Chemical Society.96, 75737574.

Cao J, Henry, P. R. Guo, R. Holwerda, R. A. Toth, J. P., Littell, R. C., Miles, R. D. and Ammerman C. B. 2000. Chemical characteristics and relative bioavailability of supplemental organic zinc sources for poultry and ruminants. Journal of Animal Science 78: 2039 54.

Caraway, W.T.1963. Standard methods of clinical chemistry (ed. D Seligron), vol. 4, p. 239.Academic Press, NY, USA.

Duncan, D.B.1955. Multiple ranges and multiple tests. Biometrics, 11: 1-42.

Ellen, B., Britanico, Florinia, Merca, , Amado, Angeles, Sonia, E., Acda A., and Edwin, P., Luis S. 2012. Effects of supplementing diets with amino acid chelates of copper, zinc, manganese and iron on the performance of broilers. Philipp. J. Vet. Anim. Sci. 38(1): 1-10.

Fawzy M.M, El-Sadawi H.A, El-Dien M.H, Mohamed WA.M. 2016. Hematological and biochemical performance of poultry following zinc oxide and sodium selenite supplementation as food additives. Ann Clin Pathol 4(4): 1076.

Feldman, B.F.; Zinkl, J.G.\& Jain, N.C. 2000. Schalm's Veterinary Hematology. Lippincott Williams and Wilkins, Philadelphia, USA.

Ghazi, S., M. Habibian, M. M. Moeini, and A. R. Abdolmohammadi.2012. Effects of different levels of organic and inorganic chromium on growth performance and immunocompetence of broilers under heat stress. Biol. Trace Elem. Res. 146:309-317.

Gheisari, A.A., Rahimi-Fathkoohi, A., Toghyani, M. and Mrhdi, M. 2010. Effects of organic chelates of zinc, manganese and copper in comparison to their inorganic sources on performance of broiler chickens. Journal of Animal \& Plant Sciences 6: 630-636.

Gross, W., and H. Siegel. 1983. Evaluation of the heterophil/ lymphocyte ratio as a measure of stress in chickens. Avian Dis. 27:972-979.

Halliwell, B., S. Chirico, M. A. Crawford, K. S. Bjerve, and $K$. F.Gey. 1993. Lipid peroxidation: its mechanism, measurement, and significance. Am. J. Clin. Nutr. 57:715-724.

Henry P.R, Ammerman C.B, Miles RD. 1989. Relative bioavailability of manganese in a manganese- methionine complex for broiler chicks. Poultry 
zinc chelate-Mn chelate- blood profile-carcass traits- immune response

Science 68: 107-112. Baker DH, Halpin KM 1987: Efficacy of manganese-protein chelate compared with that of manganese sulfate for chicks. Poult Sci 66: 1561-1563

Herzig I, Navratilova M, Totusek J, Suchy P, Vecerek V, Blahova J, Zraly Z. 2009. The effect of humic acid on zinc accumulation in chicken broiler tissues. Czech Journal of Animal Science 54: 121-27.

Idowu O M O, Ajuwon R O, Oso A O and Akinloye $O$ A. 2011.Effects of zinc supplementation on laying performance, serum chemistry and zinc residue in tibia bone, liver, excreta and egg shell of laying hens. International Journal of Poultry Science 10 (3): 22530.

Iqbal S, Deo C, Mandal AB, Tyagi PK and Awachat VB 2011. Response of feeding different sources and concentrations of zinc and copper on performance of broiler chickens. Indian Journal of Poultry Science, 46(3): 330336.

Kucuk, O., A. Kahraman, I. Kurt, N. Yildiz, and A. C. Onmaz. 2008. A combination of zinc and pyridoxine supplementation to the diet of laying hens improves performance and egg quality. Biol. Trace Elem. Res. 126:165-175.

Levander, O.A.; Deloach, D.P.; Morris, V.C. \& Moser, P.B. 1983. Platelet glutathione peroxidase activity as an index of selenium status in rats. J. Nutr., 113: 55-63.

Majkic-Singh, N.; Stojanov M; Spasic, S. and Berkes, I. 1981. Spectrophotometricdetermination of serum uric acid by an enzymatic method with 2,20-azino-di(3ethylbenzthiazoline-6-sulfonate)
(ABTS). Clinica Chimica Acta 116, 117-123.

Mohanna, C. and Nys, Y. 1998. Influence of age, sex and cross on body concentrations of trace elements (zinc, iron copper and manganese) in chickens. British Poultry Science 39: 536-543.

Nishikimi, M.; Roa, N.A.\& Yogi, K. 1972. The occurrence of superoxide anion in the reaction of reduced phenazine methosulfate and molecular oxygen.Biochem.Bioph. Res., Common., 46(2): 849-854.

NRC 1994.Nutrient Requirements for Poultry.9th rev. ed. Natl. Res. Counc., Natl. Acad. Press, Washington, DC.

Osman AM.R and Ragab M.S. 2007. Performance and carcass characteristics of broiler chicks fed diets supplemented with commercial zinc-tryptophane. 4th World Poultry Conference 27- 30 March 2007, Sharm El-Sheikh, EGYPT.

Ozturk-Urek, R., L. A. Bozkaya, and L. Tarhan .2001. The effects of some antioxidant vitamin- and trace element supplemente diets on activities of SOD, CAT, GSH- PXand LPO levels in chicken tissues. Cell Biochem. 19:125132

Parak T. and Strakova E. 2011. Zinc as a feed supplement and its impact on plasma cholesterol concentrations in breeding cocks. Acta Veterinaria Brno 80: 281-85.

Provan, D.;Singer, C.R.J.; Baglin, T. and Lilleyman, J. 2004. Oxford handbook of clinicalhematology, 2nd edition. Oxford University Press, USA.

Reitman, S.and Frankle, S.A. 1957. Colorimetric method for the determination of serum glutamic oxaloacetic and glutamic pyruvic 
Ghada Mostafa El ashry

transaminase. Am. J. Clin. Pathol., 28:56-63.

SPSS 2016.SPSS Statistics for Windows, Version 24.Armonk. NY. IBM Corp.

Tayeb, I. T. and Qader, G. K. 2012. Effect of feed supplementation of selenium and vitamin e on production performance and some hematological parameters of Broiler. J. Nat. Sci., 15(3): 46.

Tietz, N.W. 1986. Fundamentals of clinical chemistry, pp. 723.WB Saunders Company, Philadelphia, USA.

Trinder, P. 1969. Determination of glucose in blood using glucose oxydase with an alternative oxygen acceptor.Annals Clin. Biochem., 6: 24.

Underwood E J and Suttle N F. 1999. The Mineral Nutrition of Livestock. 3rd edn. CABI Publishing, Wallingford, Oxon, UK.

Van Der Klis, J.D. and A. D. Kemme, 2002. An appraisal of trace elements: Inorganic and organic, pp: 99-108. in Poultry Feedstuffs: Supply, Composition and Nutritive Value. J. M. McNab and K. N. Boorman, Ed. CAB Int. Wallingford, UK.

Vladimir P., Lode N. and Gabriel K.. 2010. Effect of dietary supplementation of trace elements on the growth performance and their distribution in the breast and thigh muscles depending on the age of broiler chickens. Acta. Vet.79: 203-209.

Wedekind K J and Baker D H. 1990. Zinc bioavailability in feedgrade sources of zinc. Journal of Animal Science 68: 684-89.

Wedekind K J, Hortin A E and Baker D H. 1992. Methodology for assessing zinc bioavailability: Efficacy estimates for zinctryptophane, zinc sulphate and zinc oxide. Journal of Animal Science 70:178-87.

Wei, J. P. J., C. Srinivasan, H. Han, J. S. Valentine and E. B. Gralla .2001. Evidance for a novel role of copperzinc superoxide dismutase in zinc metabolism. J.Biol.Chem,276:4479877803

Wellinghausen,N.,M.Martin and L.Rink, 1997.Zinc inhibits interleukin1-dependent $T$ cell stimulation Eur.J.Immunol.,27:2599-2535

Wilson W O, Ursula $K A$ and Hans A. 1961. Evaluation of Coturnix(Japanese quail) as pilot animal for poultry. Poultry Science 57(6): 1499-1502.

Woo, C., G. Prathapasinghe, Y. L. Siow, and $K$. $O$. 2006. Hyperhomocysteinemia induces liver injury in rat: Protective effect of folic acid supplementation. Biochim. Biophys. Acta-Molecular Basis Dis. 1762:656-665.

Yang XJ, Sun XX, Li CY, Wu XH and Yao JH 2011. Effects of copper, iron, zinc, and manganese supplementation in a corn and soybean meal diet on the growth performance, meat quality and immune responses of broiler chickens. Journal of Applied Poultry Research, 20: 263-271. 
الملخص العربى

تاثير التغديه بالمركبات المخلبيه للزنك والمنجنيز مع كل من البروتين والتربتوفان على معدلات

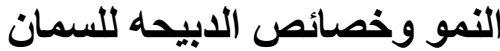

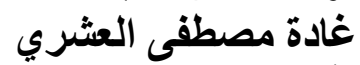

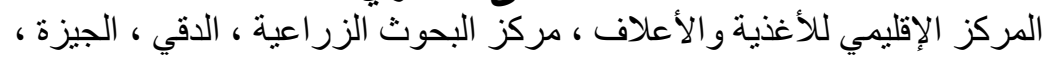

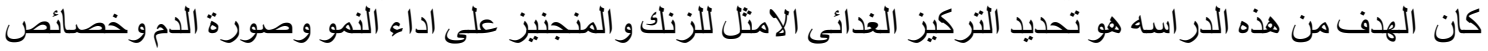

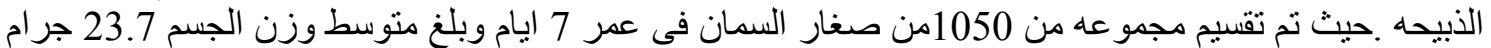

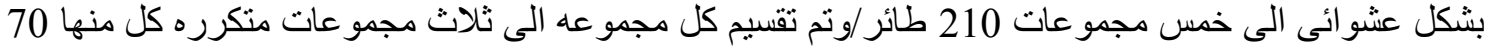

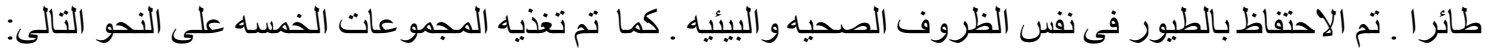

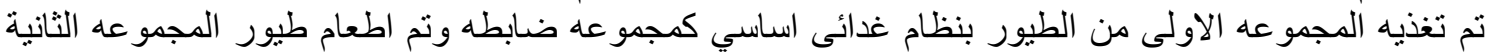

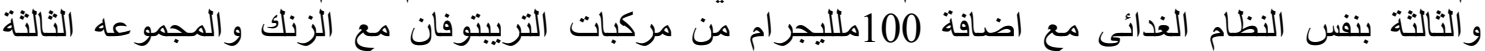

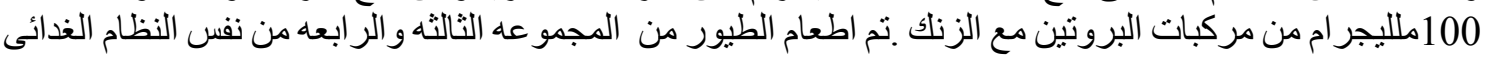

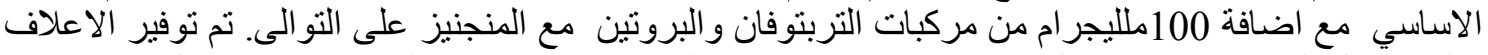

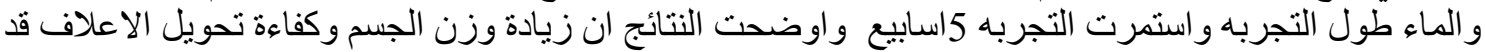

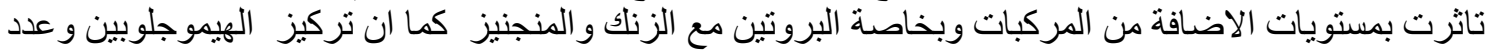

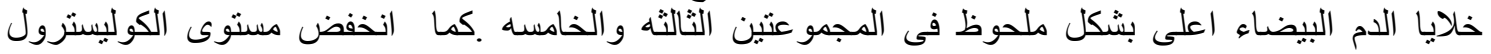

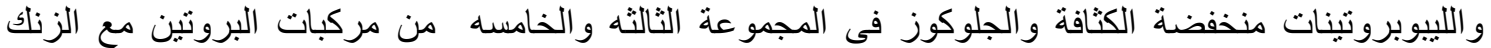

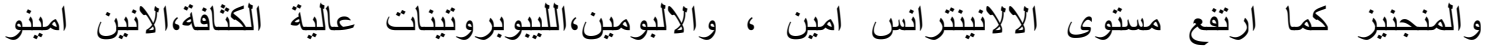

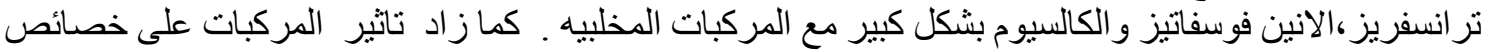

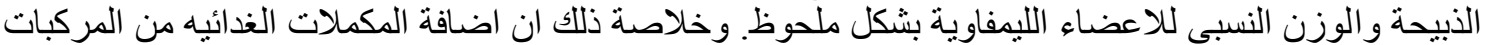

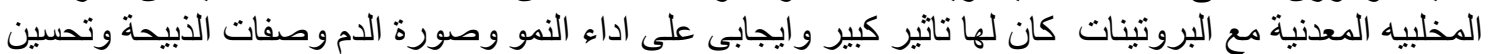

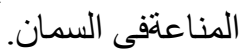

